Yüzüncü Yil Üniversitesi
Tarim Bilimleri Dergisi

Araştırma Makalesi (Research Article)

\title{
Batman Yöresinden Selekte Edilen Cevizlerin (Juglans regia L.) Bazı Meyve Özellikleri ile Makro-Mikro Element Düzeyleri**
}

\author{
Songül ACAR ${ }^{* 1}$, Ahmet KAZANKAYA ${ }^{2}$ \\ ${ }^{1}$ Zeytincilik Araştırma Enstitüsü, 35100, İzmir, Türkiye \\ ${ }^{2}$ Van Yüzüncü Y1l Üniversitesi, Ziraat Fakültesi, Bahçe Bitkileri Bölümü, 65090, Van, Türkiye \\ ${ }^{1} \mathrm{https}$ ://orcid.org/ 0000-0002-4989-4223 2https://orcid.org/ 0000-0002-1081-4281 \\ *Sorumlu yazar e-posta: songul.acar@tarimorman.gov.tr
}

\section{Makale Bilgileri}

Geliş: 04.03.2020

Kabul: 20.04.2020

Online Yayınlanma 30.06.2020

DOI: 10.29133/yyutbd.698507

Anahtar kelimeler

Batman,

Ceviz,

Makro-mikro besin elementi,

Pomoloji,

Seleksiyon.
Öz: Bu çalışmada Batman ili Kozluk ve Sason yöresinden selekte edilen 27 adet ceviz genotipinin bazı fiziksel ve kimyasal özelliklerini belirlemek amaçlanmıştır. Araştırmada genotiplerin kabuklu meyve kalınlıkları, meyve genişlikleri, meyve yükseklikleri, kabuk kalınlıkları, kabuklu meyve ağırlıkları, iç meyve ağırlıkları, iç randımanı sırasıyla 25.99-37.19 mm, 27.25-35.29 mm, 29.64-50.69 mm,1.11-2.55 mm, 8.28-17.45 g, 3.59-7.74 g, \% 36.00-58.25 arasında saptanmıştır. İç meyve rengi 13 genotipte çok açık, 10 genotipte açık, geriye kalan 4 genotipte ise orta olarak belirlenmiştir. Genotiplerde protein \% 12.15-18.30, toplam yağ \% 53.25-68.70, nem \% 1.87-3.60, kül \% 1.30-2.96 arasında değiştiği belirlenmiştir. Genotiplerin makro element içeriklerinin ortalamas1; \% 2.35 N; 285.64 mg P; 406.23 mg K; 315.83 mg Mg; 226.30 mg Ca; ve $187.71 \mathrm{mg} \mathrm{S}$ olarak tespit edilmiştir. Mikro element içerikleri $100 \mathrm{~g}$ iç meyvede ortalama Na 2.05 mg, Fe 2.51 mg, Mn 2.86 mg, Zn 2.42 mg, Cu 1.78 mg olarak saptanmıştır.

\section{Some Fruit Properties and Macro-Micro Element Contents of Selected Walnuts (Juglans regia L.) from Batman Region}

\section{Article Info}

Received: 04.03.2020 Accepted: 20.04.2020

Online Published 30.06.2020

DOI: $10.29133 /$ yyutbd.698507

Keywords

Batman,

Walnut,

Macro-Micro nutrition,

Pomology,

Selection.

\begin{abstract}
This study was carried out to determine some physical and chemical properties of 27 walnut genotypes selected from Kozluk and Sason regions of Batman. In the study, fruit thicknesses, fruit widths, fruit height, shell thicknesses, nut weights, kernel weights, kernel ratios were varied from 25.9937 to $19 \mathrm{~mm}, 27.25$ to $35.29 \mathrm{~mm}, 29.64$ to $50.69 \mathrm{~mm}, 1.11$ to $2.55 \mathrm{~mm}, 8.28$ to $17.45 \mathrm{~g}, 3.59$ to $7.74,36.00 \%$ to $58.25 \%$, respectively. Inner colors was determined as very light coloured in 13 genotypes, light coloured in 10 genotypes and medium coloured in 4 genotypes. The protein contents of selected genotypes were found between $12.15 \%$ and $18.30 \%$, oil content between $53.25 \%$ and $68.70 \%$, moisture contents between 1.87 and $3.60 \%$, ash contents between $1.30 \%$ and $2.96 \%$ and their average values were $15.74 \%$, $62.92 \%, 2.69 \%$ and $1.83 \%$, respectively. Average of macro element contents of genotypes were found 2.35\% N; $285.64 \mathrm{mg}$ P; $406.23 \mathrm{mg} \mathrm{K;} 315.83 \mathrm{mg} \mathrm{Mg;}$ $226.30 \mathrm{mg} \mathrm{Ca}$; and $187.71 \mathrm{mg} \mathrm{S}$. Average micro element contents were determined Na 2.05 mg, Fe 2.51 mg, Mn 2.86 mg, Zn 2.42 mg, Cu 1.78 mg in $100 \mathrm{~g}$ of kernel fruit.
\end{abstract}

\footnotetext{
**Çalışma birinci yazarın doktora tezinden üretilmiştir.
} 


\section{Giriş}

Anadolu cevizi, İngiliz cevizi veya İran cevizi olarak da adlandırılan ülkemizin öz meyvesi olan ceviz, dünyanın birçok yerinde ekonomik olarak yetiştirilmekte ve sert kabuklu meyveler arasında çok saygın bir yere sahip bulunmaktadır (Şen ve ark., 2011). TÜİK 2018 yılı verilerine göre Türkiye'de yaklaşık olarak 1118 bin dekar alanda toplam 215 bin ton ceviz üretimi yapılmıştır. Toplam ağaç sayısı ise 19 milyona yaklaşmışıır (Anonim, 2019).

Türkiye'de ceviz üretiminin büyük çoğunluğu, her biri ayrı özellik taşıyan ve dere kenarlarında, bağ bahçe içlerinde dağınık halde yetiştirilen ceviz çöğür ağaçlarından sağlanmaktadır (Çiftçi ve Gökçe, 2006). Bu durum ülkemizin genetik zenginliğini ortaya koymaktadır. Ülkemizin böylesine zengin bir genetik varyasyona sahip olması, sslah çalışmalarında kısa zamanda başarıya ulaşılmasına imkân sağlamaktadır (Yarılgaç, 1997; Ünver ve Sakar, 2011; Sütyemez, 2016).

Cevizin çok geniş bir kullanım alanı bulunmaktadır. Ayrıca bileşiminde insan sağlığına olumlu etkileri olan değerli besin öğelerini içermektedir (Bakkalbaşı ve ark., 2010). Ceviz içeriğini \% 13.6-22.3 oranında protein, \% 56.4-70.6 oranında yağ ve \% 2 civarında kül oluşturmaktadır. Ceviz içi bileşiminde yağda çözünen vitaminlerden A ve E vitaminleri, suda çözünenlerden C, B1, B2, folik asit, pantotenik asit ve niasin, minerallerden; demir, çinko, bakır, magnezyum ve fosfor bulunmaktadır. Cevizin iyi bir manganez ve bakır kaynağı olduğu; bu iki mineralin antioksidan korumasındaki önemli enzimlerde temel mineraller olarak kullanıldığı bildirilmistir (Yiğit ve ark., 2005). İnsanlar çok eski zamanlardan beri bazı hastalıklarının tedavisinde cevizi kullanmışlardır. Son yıllarda yapılan araştırmalarda her gün düzenli olarak iç ceviz tüketiminin hastalarda iyi kolesterolü (HDL-kolesterol) artırdığı sonucuna varılmıştır (Tufail ve ark., 2015).

$\mathrm{Bu}$ çalışmada ceviz yetiştiriciliğinin yaygın olarak yapıldığı Batman yöresinden seleksiyon yoluyla seçilen ceviz genotiplerinin fiziksel özellikleri ile bazı kimyasal bileşim öğeleri araştırılmıştır. Yapılan çalışma ile ümitvar 27 adet genotipin bazı pomolojik özellikleri ile $\mathrm{N}, \mathrm{P}, \mathrm{K}, \mathrm{Ca}, \mathrm{Mg}, \mathrm{Cu}, \mathrm{Zn}$, Mn gibi makro ve mikro besin içerikleri yanında, protein, nem, yağ ve kül miktarları da belirlenmiştir. Böylece ceviz yetiştiriciliği açışından yörenin taşıdığı önem ortaya konulmuş ve yapılacak olan 1slah çalışmalarına da kaynak oluşturulmuştur.

\section{Materyal ve Yöntem}

\subsection{Materyal}

Bu çalışmanın materyalini Batman İli, Kozluk ve Sason ilçelerinde 2014-2016 yılları arasında yürütülen seleksiyon çalışması sonucunda ümitvar olarak seçilen 27 adet ceviz genotipi oluşturmuştur. Meyve örneklerinde bazı pomolojik analizlerle birlikte, protein, nem, yağ, kül analizleri ile makro ve mikro element içeriklerine ait analizler gerçekleştirilmiştir.

\subsection{Yöntem}

İncelemeye alınan genotiplere ait meyve analizleri, ağaçların farklı yönlerinden tesadüfen seçilen meyve üzerinde gerçekleştirilmiştir. Meyvelerin pomolojik özelliklerinin belirlenmesinde UPOV kriterleri esas alınmıştır (Anonim, 1999). Genotiplerin meyve boyutları TSE ve ABD kabuklu ceviz sınıflandırmasına göre yapılmıştır (Anonim,1976; Anonim, 1990). İç renklerinin belirlenmesinde USDA İç Cevizlerin Sınıflandırması İçin Standartlar (Standards for Grades of Shelled Walnuts) kullanılmış (Anonim, 1999) ve iç renkleri DFA of California renk skalasına göre sınıflandırılmıştır (Anonim, 1976). Ayrıca genotiplerin ortalama kabuklu meyve ve iç ağırlık ölçümleri yapılarak iç randımanı \% olarak hesaplanmıştır (Şen, 1980; Yarılgaç, 1997, Muradoğlu, 2005; Yılmaz, 2007).

Çalışmada 2014 ve 2015 yıllarında yapılan değerlendirmeler sonucu "Tartılı Derecelendirme Yöntemine göre ümitvar olarak seçilen, 700 puan ve üzeri alan 27 adet genotipte öncelikle, iç ceviz meyveleri öğ̈̈tülerek nem tayinleri TSE, 1991' e göre yapılmıştır. Protein analizi için Kjeldahl (Nx6.25) metodu kullanılarak yapılmıştır (AOAC, 1990). İncelenen meyve örneklerin toplam yağ içerikleri soxhalet aletinde çözücü petrol eteri kullanılarak solvent ekstraksiyon yöntemi ile belirlenmiştir (AOACS, 1989). Örneklerin kül miktarı 0,5 gr meyve örneğinin $550{ }^{\circ} \mathrm{C}$ 'de 6 saat 
yakılması sonucunda yüzde olarak hesaplanmıştır (Şen, 1980; Akça, 1993; Yarılgaç, 1997; Yılmaz, 2007).

Ümitvar olarak seçilen ceviz genotiplerinin mineral element içeriklerini belirlemek için meyve örnekleri $68{ }^{\circ} \mathrm{C}$ 'de 48 saat boyunca kurutulmuş ve $1 \mathrm{mml}$ 'lik eleğe sahip değirmende öğütme işlemi yapılmıştır. Genotiplerin toplam azot miktarları Kjeldahl yöntemine göre Vapodest 10 kjeldahl destilasyon ünitesinde (Gerhardt, Konigswinter, Germany) tespit edilmiştir (Bremner, 1996).

Genotiplerin iç meyve örnekleri makro (P, S, K, Ca Mg ve Na) ve mikro element (Fe, Mn, Zn ve $\mathrm{Cu}$ ) içeriklerinin belirlenmesi için HNO3-H2O2 (nitrik asit + hidrojen peroksit) (2:3 v/v) karışımı ile yaş yakma (first step; $145^{\circ} \mathrm{C}, 75 \% \mathrm{RF}, 5 \mathrm{~min}$; second step; $180^{\circ} \mathrm{C}, 90 \% \mathrm{RF}, 10 \mathrm{~min}$ and third step; $100^{\circ} \mathrm{C}, 40 \% \mathrm{RF}, 10 \mathrm{~min}$ ) yöntemine göre mikrodalga aletinde hazırlanmıştır (Mertens 2005a). İç meyve örneklerinde $\mathrm{P}, \mathrm{K}, \mathrm{S}, \mathrm{Ca}, \mathrm{Mg}, \mathrm{Na}, \mathrm{Fe}, \mathrm{Mn}, \mathrm{Zn}$, ve $\mathrm{Cu}$ elementleri ISP (Inductively Couple Plasma Spectrophotometer, Perkin-Elmer, Optima 2100 DV, ICP/OES, Shelton, CT 06484-4794, USA) aletinde tespit edilmiştir (Mertens, 2005b).

\section{Bulgular}

\subsection{Seçilen genotiplerin önemli meyve özellikleri}

İncelenen 27 adet genotipin meyve kalınlıkları $37.19 \mathrm{~mm}$ (72-S-03) ile $25.99 \mathrm{~mm}$ (72-K-12), meyve genişlikleri $35.29 \mathrm{~mm}$ (72-S-03) ile $27.25 \mathrm{~mm}$ (72-K-17), meyve yükseklikleri $50.69 \mathrm{~mm}$ (72S-04) ile 29.64 mm (72-K-16) değerleri arasında değişim göstermiştir. Genotiplerin ortalama meyve kalınlığı $30.71 \mathrm{~mm}$, ortalama meyve genişliği $30.65 \mathrm{~mm}$, ortalama meyve yüksekliği $36.07 \mathrm{~mm}$ olarak hesaplanmıştır. Genotiplerin yuvarlaklık indeks değerleri en düşük 0.69 (72-S-04) ile en yüksek 1.97 (72-K-29) arasında, ortalama 0.90 olarak bulunmuştur (Çizelge 1).

Genotipler arasında kabuklu meyve ağırlıkları en düşük $8.28 \mathrm{~g}$ (72-K-149), en yüksek $17.45 \mathrm{~g}$ (72-S-04), iç meyve ağırlıkları en düşük 3.59 g (72-K-149), en yüksek 7.74 g (72-S-04) olarak ölçülmüştür. Genotiplerin iç randımanları \% 36.00 (72-K-120) ile \% 58.25 (72-K-128), kabuk kalınlıkları ise $1.11 \mathrm{~mm}$ (72-K-144) ile $2.55 \mathrm{~mm}$ (72-K-120) arasında belirlenmiştir. Kabuk kalınlıkları yönünden genotipler, 5'i orta, 22'si ise kalın kabuklu grupta yer almıştır. İncelenen genotiplerde ortalama kabuklu meyve ağırlı̆g $11.38 \mathrm{~g}$, ortalama iç ağırlığ $5.40 \mathrm{~g}$, ortalama kabuk kalınlığı $1.70 \mathrm{~mm}$ ve ortalama iç randımanı ise \% 47.99 olarak belirlenmiştir (Çizelge 1).

Selekte edilen 27 adet genotipin boş meyve oranı ortalama \% 2.35 olarak belirlenmiştir. Genotiplerden 18 adedinde boş meyveye rastlanmamıştır. Genotiplerde içte büzüşme oranı ortalama \% 2.73 olarak tespit edilirken, bu oran iç çürüklüğünde ortalama \% 1.10 olmuştur. Genotiplerden 13 adedinde içte büzüşmeye, 19 adedinde iç çürüklüğüne rastlanmamıştır. Seçilen genotiplerde ortalama $\% 4.01$ oranında iç kurdu belirlenmiş olup, 12 adet genotipte ise iç kurduna hiç rastlanmamıştır (Çizelge 1).

Genotiplerin kabuk pürüzlülüğü 12'sinde hafif, 12 genotipte orta ve 3 genotipte fazlaca pürüzlü olarak belirlenmiştir. İçin kabuktan bütün çıkma durumu 10 genotipte çok kolay, 17 genotipte kolay; iç meyve rengi 13 genotipte çok açık, 10 genotipte açık, geriye kalan 4 genotipte ise orta olarak belirlenmiştir. Genotiplerin yuvarlaklık indeks değerlerine göre meyve şekilleri 26'sında yuvarlak şekilli, sadece 1'inde ise oval şekilli olarak belirlenmiştir. TSE'e göre yapılan değerlendirmede selekte edilen genotiplerin tamamı extra sınıfında yer almıştır (Çizelge 1).

\subsection{Seçilen genotiplerin protein, yăg, nem ve kül oranları ile makro ve mikro element içerikleri}

Seçilen ceviz genotiplerinin bazı kimyasal özellikleri Çizelge 2'de verilmiştir. Ceviz genotiplerinin kimyasal bileşimi incelendiğinde en fazla bulunan bileşenin yağlar olduğu görülmektedir. Genotiplerin yağ içerikleri \% 53.25 (72-K-17) ile \% 68.70 (72-S-05) arasında; protein oranları \% 12.15 (72-S-05) ile \% 18.30 (72-K-16) arasında; nem miktarları \% 1.87 (72-K-17) ile \% 3.60 (72-K-144) arasında; kül miktarları ise \% 1.30 (72-K-135) ile \% 2.96 (72-K-27) arasında bulunmuştur. Ortalama protein oranı \% 15.74, nem miktarı ortalama \% 2.69, ortalama kül miktarı \% 1.83 , ortalama yağ oranı ise \% 62.92 olarak hesaplanmıştır. 21 adet genotipte yağ oranının \% 60'ın üzerinde olduğu tespit edilmiştir (Çizelge 2). 
Selekte edilen 27 adet genotipin makro element içeriklerine göre azot $(\mathrm{N})$ miktarı \% 1.74 (72K-17) ile \% 2.89 (72-K-118) arasında değişirken azot miktarı ortalama \% 2.35 olarak belirlenmiştir. Genotiplerde $100 \mathrm{~g}$ iç cevizdeki fosfor (P) içerikleri $196.20 \mathrm{mg}$ (72-K-17) ile $362.50 \mathrm{mg}$ (72-K-12); potasyum (K) içerikleri $260.00 \mathrm{mg}$ (72-K-16) ile $614.70 \mathrm{mg}$ (72-K-145); magnezyum (Mg) içeriği $210.40 \mathrm{mg}$ (72-K-95) ile $396.00 \mathrm{mg}$ (72-K-135); kalsiyum (Ca) içeriği $107.40 \mathrm{mg}$ (72-K-53) ile $385.70 \mathrm{mg}$ (72-K-129) ve kükürt (S) içeriği $96.80 \mathrm{mg}$ (72-K-143) ile $312.10 \mathrm{mg}$ (72-K-128) arasında tespit edilmiştir. Genotiplerin $100 \mathrm{~g}$ iç meyvedeki ortalama fosfor (P) miktarı $285.64 \mathrm{mg}$, potasyum (K) miktar1 $406.23 \mathrm{mg}$, magnezyum (Mg) miktarı $315.83 \mathrm{mg}$, kalsiyum (Ca) miktar1 $226.30 \mathrm{mg}$ ve kükürt (S) miktarı $187.71 \mathrm{mg}$ olarak hesaplanmıştır (Çizelge 2).

İncelenen 27 adet genotipin mikro element içeriklerine göre $100 \mathrm{~g}$ iç meyvede sodyum $(\mathrm{Na})$ miktarı ortalama $2.05 \mathrm{mg}$, demir (Fe) miktarı ortalama $2.51 \mathrm{mg}$, Mangan (Mn) miktarı ortalama 2.86 $\mathrm{mg}$, çinko $(\mathrm{Zn})$ miktarı ortalama $2.42 \mathrm{mg}$, bakır $(\mathrm{Cu})$ miktarı ortalama $1.78 \mathrm{mg}$ olarak belirlenmiştir. Genotiplerde en düşük ve en yüksek mineral içerikleri ise sırasıyla Na $1.12 \mathrm{mg}$ (72-K-135)- $3.14 \mathrm{mg}$ (72-K-136), Fe 1.20 mg (72-K-95)- 3.56 mg (72-S-48), Mn 1.69 mg (72-K-17)- 4.35 mg (72-K-145), Zn 1.20 mg (72-K-27)- 3.69 mg (72-S-48), Cu 0.82 mg (72-K-92)- 2.98 mg (72-K-128) olarak tespit edilmiştir (Çizelge 2). 
Çizelge 1. Seçilen genotiplerin önemli meyve özellikleri

\begin{tabular}{|c|c|c|c|c|c|c|c|c|c|c|c|c|c|c|c|c|c|}
\hline Genotip No & $\begin{array}{c}\text { MK (E) } \\
(\mathrm{mm})\end{array}$ & $\begin{array}{l}\operatorname{ME}(\mathrm{L}) \\
(\mathrm{mm})\end{array}$ & $\begin{array}{c}\text { MY (H) } \\
(\mathrm{mm})\end{array}$ & Yİ ® & $\begin{array}{c}\text { KMA } \\
\text { (g) }\end{array}$ & $\begin{array}{l}\text { İMA } \\
\text { (g) }\end{array}$ & İR (\%) & $\begin{array}{l}\mathrm{KK} \\
(\mathrm{mm})\end{array}$ & $\begin{array}{l}\text { İÇ } \\
(\%)\end{array}$ & $\begin{array}{l}\text { İB } \\
(\%)\end{array}$ & BM (\%) & İK (\%) & MŞ & Mİ & KР & İBÇ & İR \\
\hline 72-S-03 & 37.19 & 34.70 & 40.25 & 0.89 & 15.62 & 7.41 & 47.46 & 1.82 & 3.33 & 5.00 & 10.00 & 6.67 & $\overline{\mathrm{Y}}$ & $E$ & FP & ÇK & $\mathrm{O}$ \\
\hline 72-S-04 & 34.50 & 35.29 & 50.69 & 0.69 & 17.45 & 7.74 & 44.35 & 1.61 & 3.33 & 0.00 & 0.00 & 6.67 & $\mathrm{Y}$ & $\mathrm{E}$ & OP & ÇK & A \\
\hline 72-S-05 & 32.46 & 31.42 & 34.52 & 0.93 & 11.14 & 5.97 & 53.61 & 1.30 & 0.00 & 6.67 & 0.00 & 0.00 & $\mathrm{Y}$ & E & HP & ÇK & A \\
\hline 72-K-11 & 28.84 & 28.93 & 34.52 & 0.84 & 9.76 & 4.72 & 48.36 & 1.51 & 0.00 & 0.00 & 6.67 & 0.00 & $\mathrm{Y}$ & $\mathrm{E}$ & HP & ÇK & ÇA \\
\hline 72-K-12 & 25.99 & 31.87 & 38.42 & 0.75 & 12.99 & 6.31 & 48.57 & 1.65 & 0.00 & 0.00 & 0.00 & 0.00 & $\mathrm{Y}$ & $\mathrm{E}$ & HP & $\mathrm{K}$ & ÇA \\
\hline 72-K-16 & 29.81 & 29.69 & 29.64 & 1.00 & 9.30 & 4.30 & 46.24 & 1.69 & 0.00 & 5.83 & 0.00 & 0.00 & $\mathrm{Y}$ & $\mathrm{E}$ & OP & ÇK & A \\
\hline 72-K-17 & 27.88 & 27.25 & 34.98 & 0.79 & 9.32 & 4.37 & 46.89 & 1.75 & 3.33 & 0.00 & 3.33 & 3.33 & $\mathrm{Y}$ & $\mathrm{E}$ & OP & $\mathrm{K}$ & ÇA \\
\hline $72-\mathrm{K}-27$ & 28.96 & 29.27 & 38.77 & 0.75 & 11.67 & 5.43 & 46.51 & 1.91 & 3.33 & 0.00 & 0.00 & 6.67 & $\mathrm{Y}$ & $\mathrm{E}$ & HP & K & A \\
\hline $72-K-29$ & 36.28 & 33.69 & 37.64 & 1.97 & 14.20 & 5.41 & 38.10 & 1.97 & 0.00 & 10.00 & 3.33 & 10.00 & $\mathrm{O}$ & $\mathrm{E}$ & FP & $\mathrm{K}$ & $\mathrm{O}$ \\
\hline $72-S-48$ & 29.88 & 31.42 & 37.05 & 0.83 & 10.40 & 5.28 & 50.74 & 1.74 & 0.00 & 0.00 & 10.00 & 5.00 & $\mathrm{Y}$ & $\mathrm{E}$ & OP & $\mathrm{K}$ & A \\
\hline $72-S-53$ & 27.96 & 27.54 & 36.27 & 0.77 & 9.56 & 4.67 & 48.85 & 1.60 & 0.00 & 5.00 & 0.00 & 0.00 & $\mathrm{Y}$ & $\mathrm{E}$ & HP & $\mathrm{K}$ & ÇA \\
\hline 72-K-92 & 30.47 & 29.05 & 32.38 & 0.92 & 10.26 & 5.37 & 52.34 & 2.07 & 0.00 & 7.50 & 0.00 & 0.00 & $\mathrm{Y}$ & $\mathrm{E}$ & OP & K & ÇA \\
\hline 72-K-95 & 27.03 & 29.46 & 35.36 & 0.80 & 9.02 & 5.05 & 55.98 & 1.86 & 0.00 & 15.00 & 0.00 & 0.00 & $\mathrm{Y}$ & $\mathrm{E}$ & OP & $\mathrm{K}$ & ÇA \\
\hline 72-K-118 & 32.37 & 32.26 & 39.07 & 0.83 & 12.74 & 6.45 & 50.62 & 1.52 & 5.00 & 1.25 & 0.00 & 10.00 & $\mathrm{Y}$ & $\mathrm{E}$ & HP & $\mathrm{K}$ & $\mathrm{O}$ \\
\hline 72-K-120 & 34.09 & 32.06 & 36.17 & 0.91 & 15.13 & 5.45 & 36.00 & 2.55 & 0.00 & 2.50 & 0.00 & 0.00 & $\mathrm{Y}$ & $\mathrm{E}$ & OP & $\mathrm{K}$ & ÇA \\
\hline 72-K-128 & 30.10 & 30.65 & 36.08 & 0.84 & 9.97 & 5.81 & 58.25 & 1.25 & 5.00 & 0.00 & 0.00 & 5.00 & $\mathrm{Y}$ & $\mathrm{E}$ & OP & ÇK & ÇA \\
\hline 72-K-129 & 30.94 & 29.35 & 35.17 & 0.86 & 11.16 & 5.55 & 49.73 & 1.63 & 1.25 & 0.00 & 0.00 & 10.00 & $\mathrm{Y}$ & $\mathrm{E}$ & OP & ÇK & ÇA \\
\hline 72-K-135 & 29.12 & 31.00 & 35.03 & 0.86 & 10.04 & 5.33 & 53.04 & 1.64 & 0.00 & 0.00 & 10.00 & 0.00 & $\mathrm{Y}$ & $\mathrm{E}$ & FP & $\mathrm{K}$ & ÇA \\
\hline 72-K-136 & 31.39 & 30.50 & 38.17 & 0.81 & 12.27 & 5.41 & 44.09 & 1.65 & 0.00 & 0.00 & 5.00 & 5.00 & $\mathrm{Y}$ & $\mathrm{E}$ & HP & $\mathrm{K}$ & A \\
\hline 72-K-143 & 30.06 & 29.25 & 33.78 & 0.88 & 10.23 & 4.66 & 45.53 & 1.93 & 0.00 & 2.50 & 0.00 & 0.00 & $\mathrm{Y}$ & $\mathrm{E}$ & HP & K & A \\
\hline $72-K-144$ & 32.58 & 31.78 & 36.75 & 0.88 & 11.94 & 6.53 & 54.69 & 1.11 & 0.00 & 0.00 & 5.00 & 15.00 & $\mathrm{Y}$ & $\mathrm{E}$ & HP & ÇK & ÇA \\
\hline 72-K-145 & 29.40 & 31.06 & 34.81 & 0.87 & 10.36 & 5.06 & 48.82 & 1.41 & 0.00 & 0.00 & 0.00 & 5.00 & $\mathrm{Y}$ & $\mathrm{E}$ & HP & ÇK & A \\
\hline 72-K-146 & 33.22 & 31.98 & 36.29 & 0.90 & 12.27 & 5.84 & 47.84 & 1.77 & 0.00 & 2.50 & 5.00 & 0.00 & $\mathrm{Y}$ & $\mathrm{E}$ & OP & $\mathrm{K}$ & $\mathrm{O}$ \\
\hline 72-K-147 & 32.43 & 31.89 & 33.77 & 0.95 & 13.28 & 5.76 & 43.37 & 1.76 & 0.00 & 5.00 & 0.00 & 5.00 & $\mathrm{Y}$ & $\mathrm{E}$ & OP & $\mathrm{K}$ & ÇA \\
\hline 72-K-148 & 28.68 & 29.58 & 32.80 & 0.89 & 9.72 & 3.63 & 37.35 & 2.31 & 5.00 & 2.50 & 0.00 & 10.00 & $\mathrm{Y}$ & $\mathrm{E}$ & OP & ÇK & ÇA \\
\hline 72-K-149 & 28.41 & 27.84 & 35.76 & 0.79 & 8.28 & 3.59 & 46.60 & 1.54 & 0.00 & 2.50 & 5.00 & 5.00 & $\mathrm{Y}$ & $\mathrm{E}$ & HP & $\mathrm{K}$ & $\mathrm{A}$ \\
\hline 72-K-150 & 29.25 & 28.80 & 29.84 & 0.97 & 9.12 & 4.72 & 51.75 & 1.46 & 0.00 & 0.00 & 0.00 & 0.00 & $\mathrm{Y}$ & $\mathrm{E}$ & HP & $\mathrm{K}$ & A \\
\hline En düşük & 25.99 & 27.25 & 29.64 & 0.69 & 8.28 & 3.59 & 36.00 & 1.11 & 0.00 & 0.00 & 0.00 & 0.00 & & & & & \\
\hline En yüksek & 37.19 & 35.29 & 50.69 & 1.97 & 17.45 & 7.74 & 58.25 & 2.55 & 5.00 & 15.00 & 10.00 & 15.00 & & & & & \\
\hline Ortalama & 30.71 & 30.65 & 36.07 & 0.90 & 11.38 & 5.40 & 47.99 & 1.70 & 1.10 & 2.73 & 2.35 & 4.01 & & & & & \\
\hline \multirow{5}{*}{\multicolumn{3}{|c|}{$\begin{array}{l}\text { MK: Meyve Kalınlı̆̆ı } \\
\text { ME: Meyve Eni } \\
\text { BM: Boş Meyve } \\
\text { IK: Iç Kurdu } \\
\text { OP: Orta pürüzlü }\end{array}$}} & \multicolumn{5}{|c|}{ MY: Meyve Yüksekliği } & \multicolumn{3}{|c|}{ Yİ: Yuvarlaklık İndeksi } & \multicolumn{4}{|c|}{ İMA: İç Meyve Ağrılığı } & \multicolumn{3}{|c|}{ İÇ: İç Çürüklüğü } \\
\hline & & & \multirow{2}{*}{\multicolumn{5}{|c|}{$\begin{array}{l}\text { KMA: Kabuklu Meyve Ağırllı̆ } \\
\text { İBC: İ́cin Bütün Cıkma Durumu }\end{array}$}} & \multirow{2}{*}{\multicolumn{3}{|c|}{ İR: İç randımanı }} & \multicolumn{4}{|c|}{ KK: Kabuk Kalınlığı } & \multicolumn{3}{|c|}{ İB: İcte Büzüsme } \\
\hline & & & \multirow{2}{*}{\multicolumn{5}{|c|}{$\begin{array}{l}\text { IBÇ: Için Butun Ç1kma Durumu } \\
\text { KP: Kabuk Pürüzlülüğü }\end{array}$}} & & \multicolumn{4}{|c|}{ Mİ: Meyve İriliği } & \multicolumn{3}{|c|}{ İR: İç Rengi } \\
\hline & & & & & & & & & & & \multirow{2}{*}{\multicolumn{4}{|c|}{$\begin{array}{l}\text { E: Ekstra } \\
\text { K: Kolay }\end{array}$}} & \multirow{2}{*}{\multicolumn{3}{|c|}{$\begin{array}{l}\text { HP: Hafif pürüzlü } \\
\text { O: Orta }\end{array}$}} \\
\hline & & & \multicolumn{5}{|c|}{ FP: Fazlaca pürüzlü } & \multicolumn{3}{|c|}{ ÇK: Çok kolay } & & & & & & & \\
\hline
\end{tabular}


Çizelge 2. Seçilen genotiplerin protein, yăg, nem ve kül oranları ile makro ve mikro element içerikleri (100 g iç meyvede)

\begin{tabular}{|c|c|c|c|c|c|c|c|c|c|c|c|c|c|c|c|}
\hline Genotip No & Protein (\%) & Yağ (\%) & $\begin{array}{l}\text { Nem } \\
(\%)\end{array}$ & $\begin{array}{l}\text { Kül } \\
(\%)\end{array}$ & N (\%) & $\mathrm{P}(\mathrm{mg})$ & K (mg) & Mg (mg) & Ca (mg) & S (mg) & $\begin{array}{c}\mathrm{Na} \\
\text { (mg) }\end{array}$ & $\mathrm{Fe}(\mathrm{mg})$ & $\begin{array}{c}\mathrm{Mn} \\
\text { (mg) }\end{array}$ & Zn (mg) & $\begin{array}{c}\mathrm{Cu} \\
(\mathrm{mg})\end{array}$ \\
\hline 72-S-03 & 14.50 & 66.34 & 2.45 & 1.70 & 2.47 & 283.10 & 352.70 & 258.10 & 235.60 & 176.40 & 2.78 & 2.98 & 3.35 & 2.65 & 2.35 \\
\hline 72-S-04 & 16.20 & 65.83 & 2.73 & 1.50 & 2.42 & 280.30 & 399.50 & 320.60 & 293.20 & 210.10 & 1.20 & 2.92 & 3.56 & 1.30 & 2.36 \\
\hline 72-S-05 & 12.15 & 68.7 & 1.9 & 1.6 & 2.50 & 276.30 & 403.20 & 360.90 & 289.10 & 204.60 & 2.94 & 3.12 & 2.18 & 1.44 & 2.10 \\
\hline 72-K-11 & 15.42 & 58.42 & 2.61 & 2.20 & 2.60 & 258.30 & 407.90 & 329.40 & 267.10 & 159.00 & 2.38 & 1.56 & 1.76 & 2.56 & 2.10 \\
\hline 72-K-12 & 17.94 & 63.10 & 2.45 & 1.60 & 2.76 & 362.50 & 370.80 & 356.40 & 256.50 & 200.70 & 2.06 & 3.08 & 2.76 & 2.68 & 2.18 \\
\hline 72-K-16 & 18.30 & 63.00 & 2.30 & 1.84 & 1.92 & 236.10 & 260.00 & 327.20 & 121.50 & 140.60 & 1.87 & 2.69 & 2.10 & 2.46 & 1.64 \\
\hline 72-K-17 & 16.65 & 53.25 & 1.87 & 2.05 & 1.74 & 196.20 & 350.60 & 294.40 & 164.50 & 246.40 & 1.85 & 2.76 & 1.69 & 1.78 & 0.96 \\
\hline $72-K-27$ & 16.00 & 68.12 & 2.86 & 2.96 & 2.48 & 255.60 & 450.40 & 280.70 & 187.40 & 181.20 & 1.47 & 2.58 & 2.55 & 1.20 & 1.56 \\
\hline 72-K-29 & 17.82 & 60.36 & 2.12 & 2.30 & 2.10 & 284.50 & 378.40 & 266.70 & 184.70 & 187.30 & 1.63 & 2.85 & 3.15 & 2.45 & 1.54 \\
\hline $72-S-48$ & 18.25 & 64.12 & 2.41 & 1.86 & 1.87 & 339.40 & 342.60 & 220.50 & 170.60 & 216.70 & 2.87 & 3.56 & 3.89 & 3.69 & 1.96 \\
\hline 72-S-53 & 16.65 & 66.12 & 2.90 & 1.40 & 2.60 & 259.40 & 287.60 & 395.40 & 107.40 & 186.60 & 2.56 & 3.10 & 2.98 & 2.80 & 1.70 \\
\hline 72-K-92 & 17.78 & 64.02 & 3.18 & 1.50 & 1.85 & 325.70 & 535.20 & 385.00 & 234.60 & 112.50 & 1.20 & 3.00 & 3.50 & 1.80 & 0.82 \\
\hline 72-K-95 & 13.30 & 60.10 & 3.12 & 1.58 & 2.43 & 330.60 & 456.50 & 210.40 & 252.20 & 124.00 & 2.33 & 1.20 & 3.20 & 2.08 & 2.72 \\
\hline 72-K-118 & 13.22 & 65.50 & 2.74 & 1.52 & 2.89 & 286.50 & 294.50 & 287.60 & 245.80 & 239.20 & 2.10 & 2.87 & 3.76 & 3.14 & 1.32 \\
\hline 72-K-120 & 17.51 & 64.52 & 2.85 & 1.39 & 2.50 & 320.40 & 440.30 & 356.00 & 278.30 & 167.40 & 1.94 & 2.56 & 3.20 & 2.25 & 1.30 \\
\hline 72-K-128 & 16.85 & 59.42 & 2.68 & 1.72 & 2.66 & 254.10 & 310.70 & 312.40 & 316.40 & 312.10 & 2.32 & 2.10 & 2.18 & 2.50 & 2.98 \\
\hline 72-K-129 & 15.32 & 55.16 & 2.56 & 1.96 & 1.77 & 286.90 & 360.50 & 269.70 & 385.70 & 196.50 & 1.65 & 1.96 & 3.10 & 3.26 & 2.30 \\
\hline 72-K-135 & 13.85 & 65.45 & 2.85 & 1.30 & 2.20 & 285.10 & 472.00 & 396.00 & 178.80 & 186.50 & 1.12 & 2.30 & 2.85 & 2.84 & 2.03 \\
\hline 72-K-136 & 17.82 & 60.50 & 2.10 & 2.13 & 2.49 & 237.60 & 384.20 & 258.00 & 308.50 & 205.80 & 3.14 & 1.38 & 2.59 & 2.22 & 1.84 \\
\hline 72-K-143 & 15.46 & 65.21 & 3.47 & 2.46 & 2.32 & 249.70 & 420.60 & 291.30 & 208.90 & 96.80 & 2.49 & 2.77 & 3.12 & 3.55 & 1.20 \\
\hline 72-K-144 & 13.92 & 55.43 & 3.60 & 1.43 & 2.78 & 312.50 & 469.80 & 360.30 & 193.20 & 214.20 & 2.34 & 2.55 & 2.05 & 2.77 & 1.97 \\
\hline 72-K-145 & 17.48 & 68.25 & 3.20 & 1.87 & 2.50 & 310.20 & 614.70 & 328.40 & 268.50 & 182.40 & 2.16 & 2.10 & 4.35 & 2.44 & 0.86 \\
\hline 72-K-146 & 13.46 & 65.00 & 2.94 & 2.36 & 2.20 & 354.10 & 387.30 & 364.20 & 211.70 & 186.20 & 1.46 & 2.84 & 2.85 & 0.94 & 1.60 \\
\hline 72-K-147 & 14.35 & 65.12 & 2.34 & 2.10 & 2.32 & 250.20 & 468.40 & 320.60 & 176.70 & 184.20 & 1.82 & 2.34 & 2.45 & 2.35 & 1.82 \\
\hline 72-K-148 & 13.48 & 58.20 & 2.86 & 1.85 & 2.30 & 245.60 & 516.70 & 286.40 & 176.40 & 148.00 & 2.66 & 2.20 & 3.56 & 2.38 & 1.42 \\
\hline 72-K-149 & 17.35 & 63.22 & 3.40 & 1.79 & 2.40 & 300.60 & 447.50 & 305.50 & 185.20 & 226.40 & 1.25 & 2.40 & 2.20 & 3.10 & 1.85 \\
\hline 72-K-150 & 13.86 & 66.34 & 2.11 & 1.52 & 2.45 & 330.80 & 385.60 & 385.30 & 211.50 & 176.40 & 1.68 & 2.08 & 2.32 & 2.60 & 1.55 \\
\hline En düşük & 12.15 & 53.25 & 1.87 & 1.30 & 1.74 & 196.20 & 260.00 & 210.40 & 107.40 & 96.80 & 1.12 & 1.20 & 1.69 & 0.94 & 0.82 \\
\hline En yüksek & 18.30 & 68.70 & 3.60 & 2.96 & 2.89 & 362.50 & 614.70 & 396.00 & 107.40 & 312.10 & 3.14 & 3.56 & 4.35 & 3.69 & 2.98 \\
\hline Ortalama & 15.74 & 62.92 & 2.69 & 1.83 & 2.35 & 285.64 & 406.23 & 315.83 & 226.30 & 187.71 & 2.05 & 2.51 & 2.86 & 2.42 & 1.78 \\
\hline
\end{tabular}




\section{Tartıșma ve Sonuç}

2014-2016 yılları arasında yürütülen bu çalışma sonucunda seçilen 27 adet genotipin fiziksel özelliklerine ait 3 yıllık verilerin ortalama dağılımı Çizelge 1'de ayrıntılı olarak verilmiştir. Elde edilen değerler pek çok araştırıcının bulduğu değerlerle paralellik göstermektedir. Ülkemizde yapılan çalışmalarda; Arda (2006), İç Ege Bölgesinden selekte ettiği 33 genotipe ait ortalama meyve boyunu $37.12 \mathrm{~mm}$, enini $31.71 \mathrm{~mm}$ ve yüksekliğini $33.42 \mathrm{~mm}$ olarak bulmuştur. Sütyemez ve Kaşka (2006), bazı ceviz çeşitlerinde meyve ağırlıklarının, 11.27-15.85 g, iç ağılıklarının, 5.12-8.49 g kabuk kalınlıklarının 0.98-1.27 mm arasında değiştiğini bildirmişlerdir. Oğuz ve Aşkın (2007), Ermenek yöresinden seçtiği genotiplere ait meyve genişliklerinin 30.13-36.34 mm, meyve yüksekliklerinin 27.95-33.25 mm, meyve uzunluklarının 35.34-43.42 mm, kabuk kalınlıklarının 1.23-1.80 mm arasında değiştiğini kaydetmişlerdir. Yılmaz (2007), meyve kalınlıklarının 26.64-34.45 mm, meyve genişliklerinin 24.98-31.83 mm, meyve boylarının 30.61-39.75 mm, kabuk kalınlıklarının ise 0.82$1.61 \mathrm{~mm}$ arasında değiştiğini bildirmiştir. Akça ve ark. (2015), Erzincan'ın Kemah ilçesinde seçtiği genotiplerin kabuklu meyve boyu, eni ve kabuk kalınlığ değerlerini sırasıyla; 32.55-36.62 mm, 31.58$36.15 \mathrm{~mm}$ ve $1.11-2.33 \mathrm{~mm}$ arasında belirlemişlerdir.

Araştırma sonucu seçilen genotiplerin kabuklu meyve ağırlıkları, iç meyve ağırlıklar, iç randıman değerleri sırasıyla; 8.28-17.45 g, 3.59-7.74 g, \% 36.00-58.25; ortalamaları ise $11.38 \mathrm{~g}, 5.40$ g, \% 47.99 olarak belirlenmiştir. Serr (1962), 1slah materyali olarak değerlendirilecek genotiplerde iç oranının \% 50'nin üzerinde olması gerektiğini; Pandele (1968), iç oranının en az \% 45 olması gerektiğini bildirmişlerdir. Yürütülen bu çalışma kapsamında seçilen genotiplerden 19'unun iç ağırlığı 5.00 g'dan yüksek, 18 'inin kabuklu meyve ağırlığ 10.00 g'ın üzerinde bulunmuştur. Ayrıca selekte edilen genotiplerden 9'u \% 50 ve üzerinde iç randıman oranı ile Ramos (1998)'un bildirdiği önemli ceviz çeşitlerinden Franquette (\% 44.50), Pedro (\% 47.00), Chandler (\% 49.00), Cisco (\% 46.00) ve Hardley (\% 46.00) çeşitlerini geçmiştir.

İncelenen 27 genotipin 14'ünde protein oranı \% 16 ve üzerinde, 21 adet genotipte ise yağ oranı \% 60 ve üzerinde olmuştur (Çizelge 2). Ülkemizde ve yurt dışında yapılan ceviz sslah çalışmalarında incelenen materyalin protein ve yağ içeriği önemli özellikler arasında yer almaktadır. Martinez ve ark. (2010), cevizin kolayca çıkarılabilen ve rafine edilmeden tüketilebilen yağ içeriği (bazı ticari çeşitlerde $740 \mathrm{~g} / \mathrm{kg}$ ) nedeniyle besleyici bir yiyecek olduğunu belirtmişlerdir. Pandele (1968), ıslah materyali olarak değerlendirilecek çeşitlerde yağ oranının en az \% 65, protein oranının en az \% 16 düzeyinde olması gerektiğini bildirmiştir. Mitrovic ve ark. (1997), cevizin \% 50-80 oranında yă̆, \% 12-15 oranında protein, \% 3 oranında mineral madde ve \% 2.5-4 oranında düşük şeker içerdiğini belirtmişlerdir. Özcan ve Sütyemez (2019) cevizde yağ oranlarının \%60.34 ile \%64.89, protein oranlarının \%18.48 ile \% 19.65 arasında değiştiğini bildirmişlerdir. Vishansko ve Petrova (1985) tarafindan cevizlerdeki yă ve protein içeriği arasında negatif korelasyonun olduğu bildirilmiştir. Ülkemizde bu konuda yapılan çalışmalarda yağ, protein, kül ve nem oranlarını sırasıyla Oğuz ve Aşkın (2007) \% 54.07-67.63, \% 12.11-20.75, \% 1.00-2.22, \% 2.70-3.79 arasında; Yerlikaya ve ark. (2012) \% 61.32-69.35, \% 10.58-18.19, \% 1.53-1.99, \% 1.91-4.48 arasında; Taşç1 (2016) \% 52.13-66.06, \% 18.3-21.09, \% 1.07-2.24, \% 2.70-3.80 arasında bildirmişlerdir.

Genotiplerin makro element düzeyleri sirasiyla ortalama; \% $2.35 \mathrm{~N} ; 285.64 \mathrm{mg}$ P; $406.23 \mathrm{mg}$ $\mathrm{K} ; 315.83 \mathrm{mg} \mathrm{Mg} ; 226.30 \mathrm{mg} \mathrm{Ca} ; 187.71 \mathrm{mg} \mathrm{S}$ olarak bulunmuştur. Mikro element içeriklerine göre $100 \mathrm{~g}$ iç meyvede ortalama Na $2.05 \mathrm{mg}$, Fe $2.51 \mathrm{mg}$, Mn $2.86 \mathrm{mg}$, Zn $2.42 \mathrm{mg}$, Cu) $1.78 \mathrm{mg}$ olarak belirlenmiştir. (Çizelge 2). Yarılgaç ve ark. (2003), Gevaş yöresinde bu değerleri; N \% 0.208, P \% 0.019, K \% 0.041, Ca 90.3 mg, Mg $124.8 \mathrm{mg}$, Cu $1.20 \mathrm{mg}$, Mn $1.76 \mathrm{mg}$ ve Zn $2.69 \mathrm{mg}$ olarak belirlerken; Muradoğlu (2005), seçtiği genotiplerin K değerini 355.4-857.9 mg, P 272.2-522.6 mg, Ca 71.72-369.71 mg, Mg 102-481 mg, Na 11.31-25.85 mg, Zn 1.42-3.87 mg, Fe 1.04-5.28 mg, Cu 0.35$3.18 \mathrm{mg}$ ve $\mathrm{Mn}$ 0.95-3.71 mg arasında bildirmiştir. Yılmaz (2007), incelediği 12 genotipteki ortalama fosfor içeriğini $288.09 \mathrm{mg} / 100 \mathrm{~g}$, potasyum içeriğini $251.73 \mathrm{mg} / 100 \mathrm{~g}$, sodyum içeriğini $15.53 \mathrm{mg} / 100$ $\mathrm{g}$, bakır içeriğini $3.02 \mathrm{mg} / 100 \mathrm{~g}$, demir içeriğini $3.09 \mathrm{mg} / 100 \mathrm{~g}$, çinko içeriğini $3.22 \mathrm{mg} / 100 \mathrm{~g}$, mangan içeriğini $2.12 \mathrm{mg} / 100 \mathrm{~g}$ olarak belirlemiştir. Cosmulescu ve ark. (2009) tarafindan Romanya'da dokuz ceviz çeşidinin incelendiği bir çalışmada; çeşitlerin potasyum içeriğinin 357.1-499.6 mg arasında, ortalama $414.0 \mathrm{mg}$; magnezyum içeriğinin $189.2-278.1 \mathrm{mg}$ arasında, ortalama $216.6 \mathrm{mg}$ olduğu bildirmiştir. Çelik ve ark. (2011), Tavas yöresinden seçtikleri genotiplerin makro ve mikro element içeriklerini ortalama \% 2.33 N, 254.0 mg P, 362.9 mg K, 100.8 mg Mg, 126.4 mg Ca, 160.9 mg S, 
$1.97 \mathrm{mg} \mathrm{Na}, 2.46 \mathrm{mg} \mathrm{Fe}, 2.50 \mathrm{mg} \mathrm{Mn}, 2.21 \mathrm{mg} \mathrm{Zn}$ ve $1.11 \mathrm{mg} \mathrm{Cu}$ olarak belirlemişlerdir. Polat ve ark. (2015), seçtikleri 17 ceviz genotipinde mg/100 g olarak; 408.37-569.48 mg potasyum, 194.79-267.85 mg kalsiyum; 241-426 mg magnezyum; 0.72-1.43 mg bakır ve 1.93-3.47 mg çinko tespit etmişlerdir.

Bu çalışma ile Batman İli, Kozluk ve Sason ilçe ve köylerinde yetiştirilen cevizlerin fiziksel ve kimyasal özellikleri bakımından daha önce yapılan seleksiyon çalışmalarına ve birçok standart çeşide göre, benzer özelliklere sahip oldukları saptanmıştır. Makro ve mikro element düzeyleri yönünden ümitvar ceviz genotiplerinin insan beslenmesi için çok önemli olan bileşiklere sahip olduğuda belirlenmiştir. Ayrıca yörenin gelecekteki ceviz sslah programlarında büyük bir potansiyele sahip olduğu ve seçilen genotiplerin bundan sonraki ıslah çalışmalarında materyal olarak kullanılabilecekleri belirlenmiştir.

\section{Teșekkür}

Bu çalışma, Yüzüncü Yıl Üniversitesi Bilimsel Araştırma Projeleri Koordinatörlüğü’nün 2015-FBE-D100 numaralı proje desteği ile yürütülmüştür.

\section{Kaynakça}

Akça, Y. (1993). A study on breeding of Gürün walnuts (Juglans regia L.) by selection method. $\mathrm{PhD}$, Yüzüncü Y1l University, Institute of Natural and Applied Science Van, Turkey.

Akça, Y., Bilgen, Y., \& Ercişli, S. (2015). Selection of superior Persian walnut (Juglans regia L.) from seedling origin in Turkey. Acta Scientiarum Polonorum, Hortorum Cultus, 14(3), 103-114.

Anonim. (1976). United States standards for grades of walnuts (Juglans regia) in the shell. Department of agriculture agricultural, marketing service, fruit and vegetable division, fresh products branch, Reprinted-January 1997, USA.

Anonim .(1990). TSE Unshelled Walnuts. Türk Standartları Enstitüsü, Ankara.

Anonim. (1999). Guidelines for the conduct of tests for distinctness, Uniformity and stability. International union for the protection of new varieties of plants (UPOV), Geneva.

Anonim. (2019). TÜIK records. http://www.tuik.gov.tr/Start.do Erişim tarihi: 25.11.2019.

AOACS. (1989). Official Mmethods and Recommended Practices of the American Oil Chemists Society.

AOAC. (1990). Official Methods of Analysis. 15th AOAC International. Washington. DC.

Arda, E. (2006). The investigations on the breeding by the selection method of walnut (Juglans regia L.) population in inner Aegean region. $\mathrm{PhD}$, Ege University, Institute of Natural and Applied Science İzmir, Turkey.

Bakkalbası, E., Yılmaz, Ö.M., \& Artık, N. (2010). Physical properties and chemical composition of some walnut cultivars grown in Turkey. Akademik Gida 8 (1), 6-12.

Bremner, J.M. (1996). Nitrogen-total. Methods of Soil Analysis. Part III. Chemical Methods (Bartels J. M. and Bigham, J. M. eds). 3nd Ed, ASA SSSA Publisher, Agronomy. Madison, WI, USA 5, 1085-1121.

Cosmulescu, S., Bacıu, A., Achım, G., Botu, M., \& Trandafir, I. (2009). Mineral composition of fruits in different walnut (Juglans regia L.) cultivars. Notulae Botanicae Horti Agrobotanici ClujNapoca, 37 (2), 156-160.

Çelik, F., Cimrin, K.M., \& Kazankaya, A. (2011). Some physical and chemical characteristics of promising walnuts (Juglans regia L.) genotypes selected from Tavas (Denizli). YYU J. Agric. Sci., 21 (1), 42-48.

Çiftçi, K., \& Gökçe, O. (2006). A research on the socio-economical aspects and problems of walnut production in İzmir and Manisa. YYU J. Agric. Sci., 16 (1), 7-17.

Martinez, M.L., Labuckas, D.O., Lamarque, A.L., \& Maestri, D.M. (2010). Walnut (Juglans regia L.): genetic resources, chemistry, by-products. J Sci Food Agric, 90 (12), 1959-1967.

Mertens, D. (2005a). AOAC Official method 922.02. Plants preparation of laboratuary sample. Official Methods of Analysis, 18th edn. Horwitz, W, and G.W. Latimer, (Eds). Chapter 3, pp1-2, AOAC Inter. Suite 500, 481. North Frederick Avenue, Gaitherburg, Maryland 20877-2417, USA. 
Mertens, D. (2005b). AOAC Official method 975.03. Metal in plants and pet foods. Official Methods of Analysis, 18th edn. Horwitz, W, and G.W. Latimer, (Eds). Chapter 3, pp 3-4, AOAC-Int. Suite 500, 481. North Frederick Ave., Gaitherburg, Maryland 20877-2417, USA.

Mitroviç, M., Stanisavljevic, M., \& Danjanov., J.G. (1997). Biochemical composition of fruits of some important walnut cultivars and selections. Acta Horticulturae, 442, 205-207.

Muradoğlu, F. (2005). Selection of promising genotypes in native walnut (Juglans regia L.) populations of Hakkari central and Ahlat (Bitlis) districts, and genetic diversity. $\mathrm{PhD}$, Yüzüncü Y1l University, Institute of Natural and Applied Science Van, Turkey.

Oğuz, H.I.., \& Aşkın, A. (2007). A Study on the selection of walnut (Juglans regia L.) in Ermenek. YYU J. Agric. Sci., 17 (1), 21-28.

Özcan, A., \& Sütyemez, M. (2019). Cevizde depolama süresinin protein ve yağ kompozisyonuna olan etkisinin belirlenmesi, Yüzüncü Yıl Üniversitesi Tarım Bilimleri Dergisi, vol. 29, no. 4, pp. 628-633.

Pandele, L. (1968). Biochemical characterization the principal varieties and types of walnut, almond, and hazel in Romenia and determination of general metabolitic correlation specific of nuts. Pl. Br. Abstr., 38 (4), 871.

Polat, M., Okatan, V., \& Güçlü, S.F. (2015). Determination of some physical and chemical properties of walnut (Juglans regia L.) genotypes grown in the central district of Bitlis/Turkey. Scientific Papers Series B Horticulture, LIX, 81-86.

Ramos, E.D. (1998). Walnut Production Manual. University of California, Division of Agriculture and Natural Resources Communication Services Publication 3373, Oakland, California, U.S.A.

Sütyemez, M., \& Kaşka, N. (2006). Comparison of the behaivours of some localy selected genotypes and local and foreign walnut cultivars under K Maras ecological conditions, Acta, no. 705, pp. 151-157.

Sütyemez, M., (2016). New walnut cultivars Maras 18 Sutyemez 1 and Kaman 1, Hort. Science, vol. 51, no. 10, pp. 1301-1303, Nov. 2016.

Serr, E.F. (1962). Selecting Suitable Walnut Varieties. California Agricultural Experiment Station, Leaf 144. Davis, California.

Şen, S.M. (1980). A Research on breeding of walnuts (Juglans regia L.) in North East Anatolia and Eastern Black Sea Region. Associate professorship thesis, AU., Erzurum, Turkey.

Şen, S.M., Karadeniz, T., \& Beyhan, Ö. (2011). Sorularla Ceviz Yetiştiriciliği. ISBN:978-605-891503-9 ÜÇM Yayınları/5 Tarımsal Yayınlar/3, Ankara.

Taşç1, A.R. (2016). Some physical and chemical propertes of walnut genotypes (Juglans regia L.) grown in Ulubey county (Ordu). MSc, Ordu University, Institute of Natural and Applied Science Ordu, Turkey.

Tufail, S., Fatima, A., Niaz, K., Qusoos, A., \& Murad, S. (2015). Walnuts increase good cholesterol (HDL-Cholesterol) and prevent coronary artery disease. Pakistan Journal of Medical and Health Sciences, 9 (4), 1244-1246.

Ünver, H., \& Sakar, E. (2011). Walnut growing in Turkey and the state of selection studies. J.Agric. Fac. HR.U., 15 (3), 61-69.

Vishansko, Y., \& Petrova, V. (1985). Studies of chemical composition and correlations between chemical characteristics in some walnut varieties. Plant Breeding Abstracts, 055-04837.

Yarılgaç, T. (1997). Studies on breeding of walnuts (Juglans regia L.) in Gevaş district by selection method. PhD, Yüzüncü Y1l University, Institute of Natural and Applied Science Van, Turkey.

Yarılgaç, T., Özrenk, K., Muradoğlu, F., \& Tüfenkçi, Ş. (2003). Some macro-micro nutrient concentrations and pomological traits of selected walnuts (Juglans regia L.) from Gevaş district. YYU J. Agric. Sci., 13 (1), 33-37.

Yerlikaya, C., Yücel, S., Ertürk, Ü., \& Korukluoğlu, M. (2012). Proximate composition, minerals and fatty acid composition of Juglans regia L. genotypes and cultivars grown in Turkey. Brazllian Archives of Biology and Technology, 55 (5), 677-683.

Y1lmaz, S. (2007). Selection of late leafing and laterally fruitful walnut types (J. regia L.) by selection from native population. $\mathrm{PhD}$, Gaziosmanpaşa University, Institute of Natural and Applied Science Tokat, Turkey.

Yiğit, A., Ertürk, Ü., \& Korukluoğlu, M. (2005). Functional food: Walnut. Bahçe Ceviz 34 (1), 163169. 